\title{
Study of the Implementation of Socratic Dialogue at History of Physics Course
}

 \\ ${ }^{1}$ Graduate Institute of Education, National Dong Hwa University, Hualien 97401, Taiwan \\ 2Graduate Institute of Science Education, National Dong Hwa University, Hualien 97401, Taiwan \\ 3,4,6Physics Education Program, Universitas Negeri Surabaya, Surabaya 60231, Indonesia \\ 5Science Education Program, Universitas Negeri Surabaya, Surabaya 60231, Indonesia
}

\section{Article Info}

Article history:

Received January 15, 2020

Revised March 26, 2020

Accepted March 28, 2020

\section{Keywords:}

Socratic dialogue

History of physics

\begin{abstract}
Having the development of learning materials of the history of physics with Socratic learning dialogue, we implemented them to the two classes in a public university in Indonesia. The materials consisted of a lesson plan, student worksheets, evaluation sheets, and rubrics that fulfill the criteria of construct, content, and empirical validity. However, the discussion of this paper focused on the results of empirical validity. Learning materials were trialed and tested on a limited participant (10 university students from a public university in Surabaya - S), then the real classes included 40 students from a public university in Surabaya, Indonesia- S1 and S2 (20 students for each class). The data analysis technique used a descriptive statistical analysis with percentages and logical analysis. The research findings included: 1) the student's assessment of the learning materials (especially the handout and student worksheet) were categorized as good, 2) the feasibility of the learning materials during the real teaching activities obtained: the implementation of history of physics learning at S1 and S2 for each item was a quite good category, and 3) assessment of critical thinking students who are oriented Socratic dialogue showed that over $60 \%$ and $70 \%$ of S1 and S2 student answers lead to Socratic thinking, respectively. The implication of the study is the availability of physics history learning materials that are ready to be used in conducting lectures in the following semester.
\end{abstract}

\section{INTRODUCTION}

The course of the history of physics is an elective course for students of physics education program with two credits. There is no special requirement for programming this course. Although it is a selective course, this subject is very popular among students. According to the trend of student's interest in this course, it should be supported by good learning management. One of the ways taken by a researcher as well as a lecturer is to design lectures that are interesting and become more desirable starting from the preparation, implementation or process to the evaluation both in terms of the process and products. The first stage, the preparatory phase includes the readiness of the learning materials. The second stage, the implementation phase or process stage, includes media and supporting facilities, the readiness of lecturers and students. The third stage, the evaluation stage is the assessment of the lecture process and the achievement of student competencies from the lecture (Suprapto \& Dwikoranto, 2010; 2011).

The three stages have been carried out but not yet optimal; a complete and integrated package of learning materials has not yet been developed. Lecturers have not implemented learning dialogues that can increase activity, creativity, critical thinking, active 
communication, and enthusiasm, both lecturers and students. The evaluation was not comprehensive and covering the entire content to be achieved in basic competency (BC). Therefore, the implementation of lectures can be declared less than optimum. The impact of the three stages that are not ultimate raises problems in lectures. Talks become monotonous with patterns that tend to be like historical stories as lectures on history in general. Even though physics history is not like that, it must inspire and explore the critical thinking of students who do not only listen to their history. This is the root of the problem in lectures, so it needs to be solved through this research.

Meanwhile, the ideal lecture design requires students to think critically and dialectically (have communication skills), so that teaching and learning activities run well. History of physics course requires a minimum of two competencies. Lecturers need to use learning methods that stimulate students' critical and dialectical thinking. One of them is by using the Socratic dialogue (or method or model). The methods referred to from now on are the same as the dialogues undergoing development which are realized in the form of stages or syntaxes. In the next section, it will be used both terms (methods or dialogues) that are tailored to the context of Socratic dialogue.

The Socratic dialogue is actually too old to be reappointed in the field of education, but the ageing of the dialogue makes it add value, especially in terms of originality or authenticity. The Socratic dialogue is a question-and-answer learning dialogue undertaken by Socrates and his students. This dialogue is an early method of ancient learning that is still original and its existence until now as an initial framework of the formation of new learning dialogues that have been established at this time, for example, problem-based learning dialogue of critical thinking characteristics, discussion dialogue from the technical side, cooperative learning dialogue of the characteristics of teamwork or cooperation respect the opinions of others in dialogue (Qosyim, 2007; Suprapto \& Dwikoranto, 2011).

Research has been conducted by Suprapto, Zainuddin, and Supardi (2009) on the method of asking questions showed the application of guided questions could improve student performance in all aspects of scientific work in practical activities and understanding of physics concepts achieved by students. Some points can be achieved through learning by giving a series of questions. The researcher is encouraged to develop another form of questioning learning, namely the learning of the Socratic dialogue, which will be applied to lectures on the history of physics.

This research is a follow-up study that has been conducted by the researcher in the previous year. The orientation of the problem that was answered in the previous research was the profile of the results of the initial development of learning materials for the Socratic dialogue (syllabus, hand out, student worksheet, and assessment sheets) of the history of physics course. During the limited implementation of learning materials, some information has been found on the learning management, student activities, student interests, and completeness of learning outcomes in the history of physics. The formulation of the problem in the research arises because the learning materials that were developed in the first year are still in the form of a draft that requires finalization.

The aim of this research is to produce the final history of physics learning materials (syllabus, hand out, student worksheet, and assessment sheets) that meet the criteria of validity: construct, content, and empirical validity. However, the focus of discussion in this article is an empirical part.

\section{LITERATURE REVIEW}

\section{Preliminary Research}

Preliminary research has been carried out in the history of physics course for three initial meetings on the application of the Socratic dialogue in supporting the Advance Organizer (AO) in lectures. The results showed that the Socratic dialogue supports learning 
and the implementation of the $\mathrm{AO}$ in lectures on the history of physics with a gain score increases of 0.2 in the 2 nd and 3rd learning cycle compared to the acquisition of the initial cycle. Among 15 test items per cycle, there was an increase in gain score of 0.2. Supporting the implementation of the Socratic dialogue to the implementation of the AO can be seen from the increase in the student's average score. However, the results of the preliminary research were still limited to the integration of the initial organizing in learning and not yet on the teaching and learning activities of the overall history of physics and the core of the course. Research that has been done in addition to improving the core of the course also improves the quality of learning that begins with the development of learning materials. Furthermore, the Socratic dialogue developed according to the theoretical, philosophical, and scientific treasures behind the dialogue.

Meanwhile, in the first year of the project, this study obtained the results: Learning materials that have been developed by researchers include the course outline, syllabus, handout, student worksheet, assessment sheets, photos of physicists and cartoon of history of physics courses oriented to the Socratic dialogue. Regarding the application of learning materials in limited trials, the following results were obtained:

a) The ability of instructors in managing Socratic learning is categorized as good. The management results obtained in the preliminary activities and classroom atmosphere conditions showed very good categories, while for the core activities, closing and time management showed quite good categories, from the average score of observations $\geq 3.0$ per syntax stage.

b) Student activities for each activity include: active listening, reading of student handbook, working on and writing answers at student worksheet, discussing with instructors, discussing among fellow students in groups, making summaries of learning outcomes and irrelevant behaviors in succession is $14.50 \%, 13.50 \%, 16.50 \%, 27.75 \%, 20.75 \%$, $7.00 \%$ and $0.00 \%$, respectively. The largest percentage of activities is discussing with teachers, while the smallest percentage of activities is making irrelevant summaries and behaviors.

c) Student learning interest in the criteria of positive and negative statements, the average score for each condition of attention, relevance, confidence and satisfaction are 4.00 , $4.05,4.15$, and 3.45 in the good category, while the average score for all conditions is 3.91 with criteria for student interest in the good category.

d) Learning results show from the initial test on learning shows all product indicators are incomplete with an average completeness of $27.68 \%$. Then after the final test was given the results showed an average completeness of $81.67 \%$ and all items were completed.

In the first year of project, research has been carried out to the stage of limited trials, and then in the second year is perfecting physics history learning materials that have been developed and applying learning materials that have been developed in the real class.

\section{Socratic Dialogue}

The Socratic dialogue in the strict sense means how one obtains actual knowledge, so in practice that knowledge can be obtained through asking and asking questions, this is the way Socrates continues to develop in teaching his students (including Plato and Aristotle). The Socratic dialogue is an old teaching procedure that has a long history and prestige in early Greek times, taught by asking questions to guide and deepen the level of understanding related to the material taught so that students get their own thoughts from the results of cognitive conflict that is solved (Johnson \& Johnson, 2002; Qosyim, 2007).

The Socratic dialogue is critical or argumentative in the philosophical field; called the critical dialogue because using this dialogue requires people to think critically, and the result also is critical. It was called as a dialectical dialogue because this dialogue emphasizes 
dialogues of thought as an effort to express an object of discussion leading to its innermost nature (Ennis, 1991).

Lecturer skills in facilitating students to think are necessary when using this dialogue. This dialogue is designed to create thinkers automatically. Before starting learning, according to Benson (2000), some elements must be met in planning the Socratic learning dialogue, namely:

- "The teacher and student must agree on the topic of instruction".

- "The student must agree to attempt to answer questions from the teacher".

- "The teacher and student must be willing to accept any correctly-reasoned answer". That is, the reasoning process must be considered more important than preconceived facts or beliefs.

- "The teacher's questions must expose errors in the students' reasoning or beliefs. That is, the teacher must reason more quickly and correctly than the student, and discover errors in the students' reasoning, and then formulate a question that the students cannot answer except by a correct reasoning process. To perform this service, the teacher must be very quick-thinking about the classic errors in reasoning".

- "If the teacher makes an error of logic or fact, it is acceptable for a student to correct the teacher" (Benson, 2000).

The Socratic dialogue is a dialogue that can help make it easier for students to get a series of understandings from the forms of question and answer conducted. The forms of procedural stages carry out questions and answers as did Socrates in teaching material with imitating behavior carried out by the Socratic teacher, obtained from written sources in his book Johnson \& Johnson (2002) entitled: The meaningful assessing, precisely in chapter 11: Interviewing students; page 194.

Based on the guidelines of Benson (2000) and Johnson \& Johnson (2002), in general, the implementation of learning consists of three main stages, namely initial activities, core activities, and final activities. Modifications of the Socratic learning flow in the form of a Socratic core learning scheme are shown in Figure 1 below. 
Careful to observation of the phenomenon, study of objects certain or facts that have strong relevance to the learning objectives



Figure 1. The complete scheme of Socratic Learning (Qosyim, 2007; Suprapto \& Dwikoranto, 2009a; 2009c; 2010; 2011) 


\section{Research Roadmap}

This research is motivated by the incomplete state of the history of physics learning materials. The step taken by the researcher is to carry out activities to develop learning materials oriented to the Socratic dialogue that was designed for two years. In the first year, a physics learning prototype was produced which was then trialed to a physics student at S1. Furthermore, in the second year, the history of physics learning materials will be finalized so that it has content, construction, and empirical validity. It was related to empirical validity explored through real teaching activities in physics students of S1 and S2. Schematically, the framework of this research is shown in Figure 2 below.

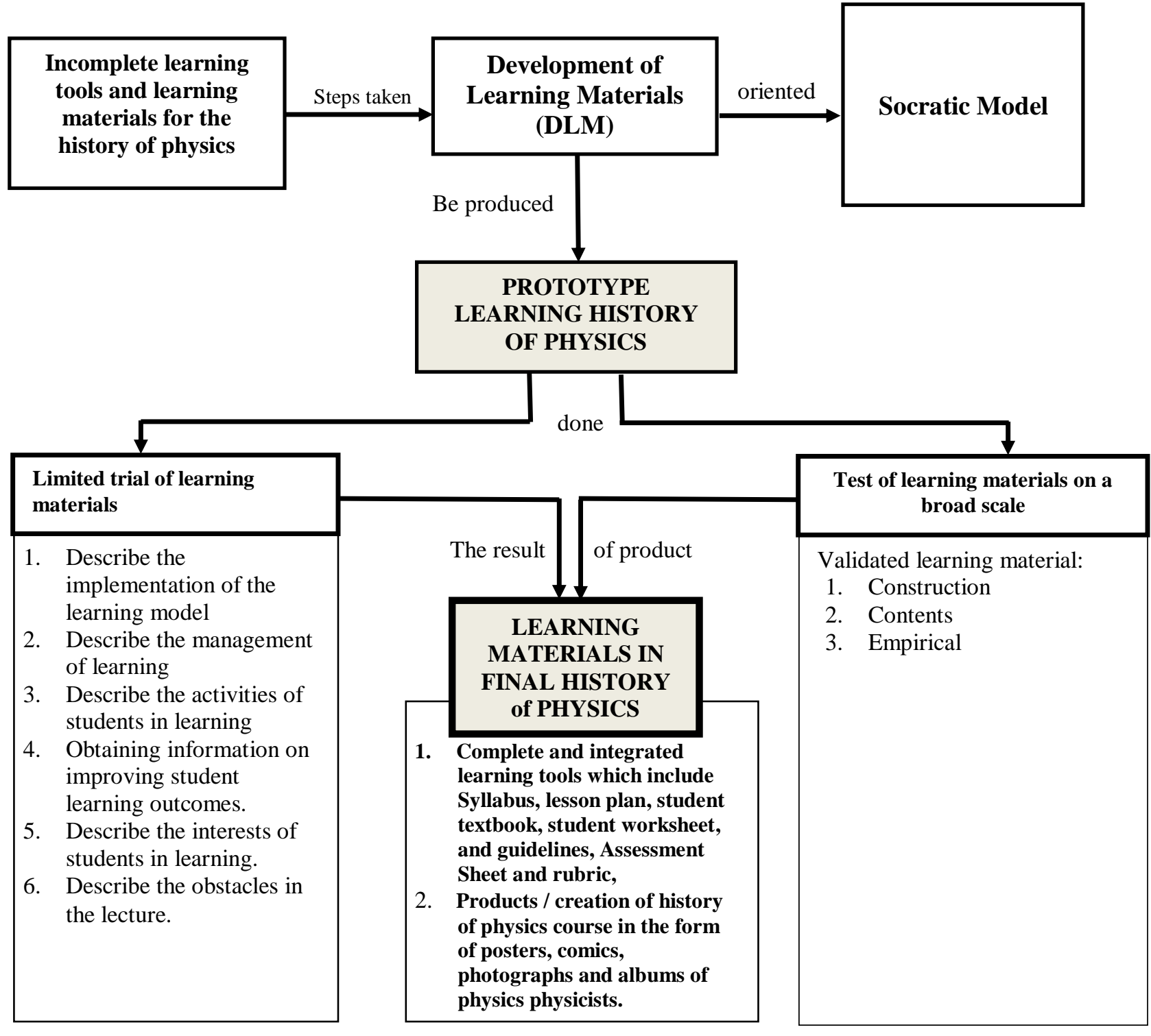

Figure 2. Research Framework (Suprapto \& Dwikoranto, 2009c)

\section{RESEARCH METHOD}

The paradigm used as inspiration in the design of this study is the Four-D Model paradigm (Thiagarajan, Semmel, \& Semmel, 1974). The results of the development of complete learning materials in the history of physics courses include in the form of syllabus, lesson plan, hand out, student worksheet and its guidance, assessment sheet, and rubrics. 
Furthermore, related to the implementation of learning materials empirically conducted real class activities.

\section{Research Procedure}

Before entering into the research procedure, it is important to report the things that have been done by the previous researcher (the first year). The research team has carried out the initial development activities of learning the history of physics and was tested on a limited scale. The intended learning material was developed based on academic and pedagogical principles, but it has not been validated empirically through the research paradigm. Research procedures that have been carried out by the research team refer to Suyono et al. (2009: 31).

\section{Participants}

In accordance with the research design and procedures above, the research objectives are all devices compiled by all research teams and phenomena during the real teaching activities. Sources of data in this study are: reviewers from the field of physics and physics education, research teams (observers in trials), and students involved in real teaching activities, namely students of history of physics program majoring in physics as group of S1 and S2 (twenty students each group).

\section{Empirical Validity Technique}

Empirical validity is determined based on the results: 1) student's assessment of the physical and content of the material that has been written by the research team, 2) appraisal of the equipment's feasibility by the development team during real teaching activities, and 3) evaluation of critical thinking of students oriented Socrates. The process of obtaining data related to empirical validity was carried out in two groups namely S1 and S2.

\section{Data Analysis}

Data collected from validator sources, learning observers, lecturers, and students can basically be classified into attribute data types (good / moderate / poor / not good, can / cannot, valid / invalid, positive / negative, feasible / not feasible, easy / being difficult to understand, and the like) which is manifested in statement sentences and research results. Several attributes are quantified to facilitate analysis. So the data analysis technique used was descriptive statistical analysis with percentages and logical analysis (Suyono et al., 2009).

\section{FINDINGS AND DISCUSSION}

\section{Findings of Empirical Validity}

As stated in the research methods section, empirical validity is determined based on the results of: 1) student's assessment of the physical and content of the equipment written by the research team, 2) assessment of the equipment's feasibility by the development team during real teaching activities, and 3) assessment of Socratic oriented student critical thinking.

a. The results of the physical assessment and the contents of the student handout and worksheet

The results of student assessment of the physical and content of the textbook and student worksheet materials that have been written by the research team are shown in Table 1. 
Table 1. Results of physical assessment of students' handout and worksheet by students

\begin{tabular}{|c|c|c|c|c|c|}
\hline \multirow[t]{2}{*}{ No. } & \multirow[t]{2}{*}{ Item Question } & \multicolumn{2}{|c|}{$\begin{array}{l}\text { Percentage of answer } \\
\text { (S1) }\end{array}$} & \multicolumn{2}{|c|}{$\begin{array}{l}\text { Percentage of answer } \\
\text { (S2) }\end{array}$} \\
\hline & & Yes (\%) & No (\%) & Yes (\%) & No (\%) \\
\hline & Student's handout & & & & \\
\hline 1. & $\begin{array}{l}\text { Is the contents of this student handout } \\
\text { interesting }\end{array}$ & 100 & 0 & 100 & 0 \\
\hline 2. & $\begin{array}{l}\text { Is the appearance of this student handout } \\
\text { interesting }\end{array}$ & 80 & 20 & 70 & 30 \\
\hline 3. & $\begin{array}{l}\text { Does this student handout awaken you in } \\
\text { learning }\end{array}$ & 90 & 10 & 70 & 30 \\
\hline 4. & $\begin{array}{l}\text { Is the description or explanation on the } \\
\text { student handout easy to understand }\end{array}$ & 60 & 40 & 70 & 30 \\
\hline \multirow[t]{2}{*}{5.} & $\begin{array}{l}\text { Are there illustrations or drawings from } \\
\text { student handout that are difficult to } \\
\text { understand or unclear }\end{array}$ & 20 & 80 & 10 & 90 \\
\hline & Student worksheet & & & & \\
\hline 1. & $\begin{array}{l}\text { Are the contents of this student worksheet } \\
\text { interesting }\end{array}$ & 90 & 10 & 80 & 20 \\
\hline 2. & Did this student worksheet look interesting & 80 & 20 & 80 & 20 \\
\hline 3. & $\begin{array}{l}\text { Does this student worksheet excite you in } \\
\text { learning }\end{array}$ & 80 & 20 & 80 & 20 \\
\hline 4. & $\begin{array}{l}\text { Is the description or explanation in student } \\
\text { worksheet easy to understand }\end{array}$ & 70 & 30 & 90 & 10 \\
\hline 5. & $\begin{array}{l}\text { Are there illustrations or drawings from } \\
\text { student worksheet that are difficult to } \\
\text { understand or unclear }\end{array}$ & 20 & 80 & 20 & 80 \\
\hline
\end{tabular}

The numbers or percentages in Table 2 present a comparison of the number of student as respondents who gave an evaluation of each question item. With this data for example an analysis of $90 \%$ of respondents $(0.9 \times 20=18$ students $)$ can be given an assessment that the contents of the student worksheet are interesting. From the overall available data, it can be given the results of an analysis that generally the student handbook and worksheet developed are interesting, motivating, and the explanations are easy to understand.

b. The results of the appraisal / feasibility of the learning materials by the observer

Lecturer activities were observed by two observers using the learning management observation sheet as shown in Tables 2 and 3. 
Table 2. Observation results of learning management with Socratic dialogue (at S1)

\begin{tabular}{|c|c|c|c|c|}
\hline \multirow{2}{*}{ No } & \multirow{2}{*}{ Aspect that is observed } & \multicolumn{3}{|c|}{ Rating Scale (in $\%$ ) } \\
\hline & & 2 & 3 & 4 \\
\hline \multirow[t]{13}{*}{ I } & \multicolumn{4}{|l|}{ Observation to teaching and learning activities } \\
\hline & \multicolumn{4}{|l|}{ A. Introduction ( \pm 10 Minute $)$} \\
\hline & 1. Teachers prepare and open lectures & & & 100 \\
\hline & $\begin{array}{l}\text { 2. The teacher conveys learning objectives that include the } \\
\text { basic competencies to be achieved in this meeting. }\end{array}$ & & & 100 \\
\hline & $\begin{array}{l}\text { 3. The teacher motivates students by drawing attention to the } \\
\text { material to be taught. }\end{array}$ & & & 100 \\
\hline & 4. The teacher informs the learning method used & & & 100 \\
\hline & \multicolumn{4}{|l|}{ B. Core Activities ( \pm 80 Minute $)$} \\
\hline & $\begin{array}{l}\text { 1. The teacher asks opening questions to students to begin } \\
\text { learning. }\end{array}$ & & & 100 \\
\hline & $\begin{array}{l}\text { 2. The teacher gives observational questions to see student } \\
\text { responses for each learning goal. }\end{array}$ & & & 100 \\
\hline & $\begin{array}{l}\text { 3. The teacher gives inland questions, with the aim of } \\
\text { responding to the cognitive conflict of students at each } \\
\text { learning goal }\end{array}$ & & & 100 \\
\hline & $\begin{array}{l}\text { 4. The teacher asks the conclusion question, to gain more } \\
\text { complete knowledge of the cognitive conflict resolution } \\
\text { process, at each learning goal }\end{array}$ & & & 100 \\
\hline & $\begin{array}{l}\text { 5. The teacher assigns students to answer evaluation questions, } \\
\text { at each specified learning goal, as class discussion material, } \\
\text { which was previously discussed in their respective study } \\
\text { groups. }\end{array}$ & & & 100 \\
\hline & $\begin{array}{l}\text { 6. The teacher leads the class discussion in a guided manner, } \\
\text { with a Think-Pair-Share pattern }\end{array}$ & & & 100 \\
\hline & \multicolumn{4}{|l|}{ C. Closing ( \pm 10 Minute $)$} \\
\hline & $\begin{array}{l}\text { 1. Teachers provide conclusions and preasure on the acquisition } \\
\text { of understanding that must be mastered by students }\end{array}$ & & 50 & 50 \\
\hline & $\begin{array}{l}\text { 2. The teacher closes the lecture accompanied by an explanation } \\
\text { of additional activities as structured assignments to students } \\
\text { to work on in groups. }\end{array}$ & & & 100 \\
\hline \multirow[t]{3}{*}{ II } & Time Management and Teaching and Learning Activities & & & \\
\hline & 1. Time according to allocation & & & 100 \\
\hline & $\begin{array}{l}\text { 2. Learning activities show the characteristics of the Socratic } \\
\text { method }\end{array}$ & & & 100 \\
\hline \multirow[t]{3}{*}{ III } & Class Situation & & & \\
\hline & 1. Students are enthusiastic & & & 100 \\
\hline & 2. Enthusiastic teacher & & & 100 \\
\hline
\end{tabular}

Note: a $100 \%$ number in the scale 4 column means that both observers rate well

Based on Table 2, it appears that during the implementation of history of physics learning at S1 for each item categorized activity are quite good and good. Lecturers can manage the allocation of time well. The learning carried out made students and lecturers enthusiastic. Implementation of learning centered on students or students actively learning. 
Table 3. Observation results of learning management with Socratic dialogue (at S2)

\begin{tabular}{|c|c|c|c|c|}
\hline \multirow{2}{*}{ No } & \multirow{2}{*}{ Aspect that is observed } & \multicolumn{3}{|c|}{ Rating Scale (in $\%$ ) } \\
\hline & & 1 & 3 & 4 \\
\hline \multirow[t]{13}{*}{$\mathrm{I}$} & \multicolumn{4}{|l|}{ Observation to teaching and learning activities } \\
\hline & \multicolumn{4}{|l|}{ A. Introduction ( \pm 10 Minute) } \\
\hline & 1. Teachers prepare and open lectures & & & 100 \\
\hline & $\begin{array}{l}\text { 2. The teacher conveys learning objectives that include the } \\
\text { basic competencies to be achieved in this meeting. }\end{array}$ & & & 100 \\
\hline & $\begin{array}{l}\text { 3. The teacher motivates students by drawing attention to the } \\
\text { material to be taught. }\end{array}$ & & & 100 \\
\hline & 4. The teacher informs the learning method used & & & 100 \\
\hline & \multicolumn{4}{|l|}{ B. Core Activities ( \pm 80 Minute $)$} \\
\hline & $\begin{array}{l}\text { 1. The teacher asks opening questions to students to begin } \\
\text { learning. }\end{array}$ & & & 100 \\
\hline & $\begin{array}{l}\text { 2. The teacher gives observational questions to see student } \\
\text { responses for each learning goal. }\end{array}$ & & & 100 \\
\hline & $\begin{array}{l}\text { 3. The teacher gives inland questions, with the aim of } \\
\text { responding to the cognitive conflict of students at each } \\
\text { learning goal }\end{array}$ & & & 100 \\
\hline & $\begin{array}{l}\text { 4. The teacher asks the conclusion question, to gain more } \\
\text { complete knowledge of the cognitive conflict resolution } \\
\text { process, at each learning goal }\end{array}$ & & & 100 \\
\hline & $\begin{array}{l}\text { 5. The teacher assigns students to answer evaluation questions, } \\
\text { at each specified learning goal, as class discussion material, } \\
\text { which was previously discussed in their respective study } \\
\text { groups. }\end{array}$ & & 50 & 50 \\
\hline & $\begin{array}{l}\text { 6. The teacher leads the class discussion in a guided manner, } \\
\text { with a Think-Pair-Share pattern }\end{array}$ & & & 100 \\
\hline & \multicolumn{4}{|l|}{ C. Closing ( \pm 10 Minute) } \\
\hline & $\begin{array}{l}\text { 1. Teachers provide conclusions and preasure on the acquisition } \\
\text { of understanding that must be mastered by students }\end{array}$ & & 50 & 50 \\
\hline & $\begin{array}{l}\text { 2. The teacher closes the lecture accompanied by an explanation } \\
\text { of additional activities as structured assignments to students } \\
\text { to work on in groups. }\end{array}$ & & & 100 \\
\hline \multirow[t]{3}{*}{ II } & \multicolumn{4}{|l|}{ Time Management and Teaching and Learning Activities } \\
\hline & 1. Time according to allocation & & 50 & 50 \\
\hline & $\begin{array}{l}\text { 2. Learning activities show the characteristics of the Socratic } \\
\text { method }\end{array}$ & & & 100 \\
\hline \multirow[t]{3}{*}{ III } & Class Situation & & & \\
\hline & 1. Students are enthusiastic & & & 100 \\
\hline & 2. Enthusiastic teacher & & & 100 \\
\hline
\end{tabular}

Based on Table 3, it can be seen that when implementing history of physics learning at S2 for each item categorized as quite good and good. Lecturers can manage the allocation of time well. The learning carried out made students and lecturers enthusiastic. 


\section{c. Results of Assessment of Socratic oriented student critical thinking}

Profile of students' critical thinking is explored through mapping of answers to questions referring to the Socratic dialogue which is implemented at the end of the semester. The question consists of 5 items that are considered to represent the entire material of physical history. The following is a sample of the answers' profile of S1 Physics students from each of the questions in Socratic oriented critical thinking.

Question 2: Why is there a periodization of classical physics and modern physics? What is the dividing barrier between the two? What are the weaknesses of classical physics compared to modern physics? Are there classical physical phenomena that cannot be explained by modern physics and vice versa?

Table 4. Answer formulation leading to Socrates

\begin{tabular}{|c|c|c|c|}
\hline Student answer formulation & $\begin{array}{l}\text { Score } \\
(1-10)\end{array}$ & $\begin{array}{c}\text { The number of } \\
\text { similar } \\
\text { answers from a } \\
\text { total of } 20 \\
\text { students }\end{array}$ & $\mathrm{P}(\%)$ \\
\hline $\begin{array}{l}\text { The reasons for the periodization of classical physics with } \\
\text { modern physics are: } \\
\text {-The existence of classical physics phenomena that cannot } \\
\text { be explained by modern physics and vice versa. } \\
\text {-to distinguish the basic theories of classical physics that } \\
\text { apply to material that is macro in nature with the basic } \\
\text { theories of modern physics based on material that is micro. } \\
\text { Things that become a divider between classical physics } \\
\text { and modern physics are the size of objects and the speed of } \\
\text { objects, the limits of the validity of classical physics and } \\
\text { modern physics in explaining phenomena and .................... }\end{array}$ & 9 & 2 & 10 \\
\hline $\begin{array}{l}\text { Because of the limitations between the two in explaining } \\
\text { natural phenomena. The partition between the two is size } \\
\text { and.. }\end{array}$ & 8 & 3 & 15 \\
\hline \multicolumn{4}{|l|}{ (n) } \\
\hline Total & & & 90 \\
\hline
\end{tabular}

Table 5. Formulation of answers less relevant to Socrates

\begin{tabular}{lccc}
\hline \multicolumn{1}{c}{ Student answer formulation } & $\begin{array}{c}\text { The number of } \\
\text { similar } \\
(1-10)\end{array}$ & $\begin{array}{c}\text { Score } \\
\text { answers from } \\
\text { a total of 20 } \\
\text { students }\end{array}$ & $\mathrm{P}(\%)$ \\
\hline $\begin{array}{l}\text { There is a periodization of classical physics and } \\
\text { modern physics due to the existence of science and } \\
\text { technology at that time, in classical physics only } \\
\text { discusses macro matter while in modern } \\
\text { physics..................................................... }\end{array}$ & 5 & 2 & 10 \\
\hline
\end{tabular}

The total recapitulation of the critical thinking patterns of S1 and S2 groups of students is shown in Table 6 below: 
Table 6. Results of Socratic Oriented Critical Thinking

\begin{tabular}{clcc}
\hline \multirow{2}{*}{ Question item } & \multicolumn{1}{c}{ Answer criteria } & \multicolumn{2}{c}{ Assessment scale (in percent) } \\
\cline { 3 - 4 } & & S1 & S2 \\
\hline 1 & Leading to Socrates' thinking & 90 & 80 \\
\hline & Not relevant & 10 & 20 \\
\hline 2 & Leading to Socrates' thinking & 90 & 75 \\
\hline & Not relevant & 10 & 25 \\
\hline 3 & Leading to Socrates' thinking & 75 & 80 \\
\hline & Not relevant & 25 & 20 \\
\hline 4 & Leading to Socrates' thinking & 95 & 80 \\
\hline 5 & Not relevant & 5 & 20 \\
\hline & Leading to Socrates' thinking & 65 & 70 \\
\hline & Not relevant & 35 & 30 \\
\hline
\end{tabular}

The numbers or percentages in Table 6 represent the comparison of relevant and irrelevant answers to Socrates' critical thinking for each question. With this data, for example, an analysis can be given that $65 \%$ of S1 students 'answers to item $5(0.65 \times 20=13$ students) mean that they are directed at Socrates' thinking. Additionally, the results of analysis of $30 \%$ of the answers of S2 students in item $5(0.30 \times 10=3$ students $)$ means that the answers are less relevant. So it can be said that over $60 \%$ of S1 student answers lead to Socrates 'thinking and above $70 \%$ of S2 student answers lead to Socrates' thinking.

\section{Discussion}

The Socratic dialogue-oriented physics learning material has been developed. The learning materials consist of Syllabus, Student handout, Student Activity Sheet (student worksheet) and guidelines, Assessment Sheet and rubric. Each of these materials has been described in the previous section.

Discussion of the results of research into the development of learning materials is based on the study of the validators and their supporting devices. Based on the study of the validators, it is known that in general, the learning materials developed have been feasible and can be used with improvements. All learning materials developed have met the empirical validity requirements. The results of the analysis with a focus on empirical validity obtained the following results: 1) students' assessments of the physical and content of the materials (specifically the handout and student worksheet) that have been written by the research team in the good category. The students and student worksheet that were developed were interesting, aroused motivation, and the explanations were easy to understand, 2) the appraisal/feasibility of the equipment by the development team during the real teaching activities, the results were obtained: the implementation of history of physics learning at S1 and S2 for each item was quite good and well. Lecturers can manage the allocation of time well. The learning carried out made students and lecturers enthusiastic. The implementation of learning centered on students or students actively learning, and 3) assessment of critical thinking students who are oriented Socratic shows that over $60 \%$ of S1 student answers lead to Socratic thinking and above $70 \%$ answers S2 students lead to Socratic thinking.

The students' critical thinking patterns are in line with the core of the Socratic dialogue (Jannah \& Suprapto, 2014). This dialogue is a critical dialogue or dialectical dialogue in the philosophical field. It was called the critical dialogue because when using this dialogue requires people to think critically, and the end result also is critical. Meanwhile, it was called as a dialectical dialogue due to this dialogue emphasizes dialogues of thought as an effort to express an object of discussion leading to its innermost nature (Ennis, 1991). 


\section{The conception of research result}

How important this research is to be based on the flow of thought in the form of narrative is as follows: "Description of the course of physics history is the study, discussion, growth and development of ideas of physical concepts from Lagrange, Newton, Lorentz, until now, views on physical nature since ancient times until now and the impact on society according to its time". This course establishes the relationship between the fields of physics with each other ranging from ancient nature to current physics issues. Based on researchers' observations, history of physics learning materials that are available and have been developed at this time are syllabus and lecture handout (Santoso, 1990; Suprapto \& Dwikoranto, 2010; 2011; 2019). While other learning materials (lesson plan, student worksheet, evaluation guides, learning instruments (activities, responses) have not yet been developed, bearing in mind that physics is constantly evolving so that it requires the latest editions of learning support supplements to be in accordance with the development of science. Physics products always develop from year to year so that the recording material (in this case the history of physics) must also be new.

Serious efforts in the provision of physics history learning materials have been pursued through research. The materials developed by the research team have been validated by experts who have competence and relevance. The validity test of construction and content has been carried out by physicists and physics and science learning. Empirical validity tests have been conducted in the form of physics learning at S1 and S2. The availability of validated history of physics learning materials that meets the quality requirements support the achievement of student competencies in learning physics. Students know and interpret the flow of physicists' thoughts to their conceptual findings.

\section{CONCLUSION}

The conclusions that can be drawn from this study are the final histories of physics learning materials that have been developed are stated to meet the requirements of empirical validity. Based on the findings and constraints during the study, a number of things are recommended:

a) It is necessary to make a habit of learning or lectures by emphasizing the question and answer activity as in the Socratic dialogue as an effort to explore student knowledge from cognitive conflict.

b) Follow-up research needs to be done on affective and psychomotor activities when using this dialogue.

c) The ability related to soft skills (especially building character) of students should also be considered in this dialogue.

In the implementation of the evaluation, it would be more appropriate if the assessment used the oral examination assessment, but the consequence of allocating time for each student requires a lot of time.

\section{REFERENCES}

Benson, H. (2000). Socratic Wisdom (Oxford: Oxford University Press). Retrieved from http://en.wikipedia.org/wiki/Socratic_method.

Ennis, R. H. (1991). An elaboration of a cardinal goal of science instruction. Educational Philosophy and Theory, 23(1), 31-43.

Jannah, A. N., \& Suprapto, N. (2014). Pengaruh penerapan pembelajaran Socrates terhadap keterampilan berpikir kritis dalam pembelajaran fisika pada materi hukum Newton. Jurnal Inovasi Pendidikan Fisika, 3(2), 20-26. 
Johnson, D. W. \& Johnson, R. T. (2002). The meaningfull assessing: A manageable and cooperative process. Allyn and Bacon.

Qosyim, A. (2007). Metode Sokrates (Sokrates Method). Studi Implikasi Metode Sokrates dalam Praktek Pendidikan (makalah tidak dipublikasikan).

Santoso, M. (1990). Sejarah Fisika. Surabaya: Upress IKIP Surabaya.

Suprapto, N. \& Dwikoranto. (2019). Sejarah Fisika. Surabaya: JDS.

Suprapto, N., \& Dwikoranto. (2011). Development of learning materials with Socratic model at history of physics. Jurnal Penelitian Fisika dan Aplikasinya, 1(1), 14-22.

Suprapto, N., \& Dwikoranto. (2010). Kajian empiris pengembangan perangkat pembelajaran model sokrates pada mata kuliah Sejarah Fisika. Seminar Nasional Hasil-hasil Penelitian yang diselenggarakan oleh Lemlit Unesa

Suprapto, N. \& Dwikoranto. (2009a). Pengembangan bahan pembelajaran (PBP) model Socrates mata kuliah sejarah fisika di Jurusan Fisika FMIPA UNESA. Laporan Penelitian Hibah Bersaing Tahun Pertama.

Suprapto, N. \& Dwikoranto. (2009b). Development of learning materials with Socratic model at history of physics. Proceeding of International Seminar and Workshop on Mathematics and Science Teaching Innovation (ISW MSTI) at the FMIPA UNY, December 12th.

Suprapto, N. \& Dwikoranto. (2009c). Pengembangan bahan pembelajaran (PBP) model Socrates mata kuliah sejarah fisika di Jurusan Fisika FMIPA UNESA. Laporan Penelitian Hibah Bersaing Tahun Kedua.

Suprapto, N. \& Qosyim, A. (2007). Penerapan dialogue Sokrates (Socratic method) untuk menunjang Advance Organizer pada perkuliahan Sejarah Fisika. Prosiding No ISBN 978-97917494-0-4. Makalah dipresentasikan dalam Seminar Fisika UNAIR tanggal 4 September 2007 di Hotel Elmi Surabaya.

Suprapto, N., Zainuddin, A., \& Supardi, Z. A. (2009). Penerapan guided question pada model Guided Discovery pada kegiatan praktikum fisika sebagai upaya meningkatkan kinerja dan pemahaman konsep mahasiswa pada perkuliahan Fisika Dasar 1. Laporan Penelitian Grant Kelas Internasional.

Suyono, Ducha, N., \& Suprapto, N. (2009). Pengembangan perangkat pembelajaran IPA terpadu $S M P$ berbasis eksplorasi alam. Laporan Penelitian Strategis Nasional. Lembaga Penelitian UNESA.

Thiagarajan, S., Semmel, D., \& Semmel, M.I. (1974). Instructional development for training teachers of exeptional children. Source Book Bloomington: Center for Innovation on Teaching the Handicapped. 